\title{
Population Dynamics of Large Herbivores and the Framing of Wildlife Conservation in Zimbabwe
}

\author{
Edson Gandiwa $a^{1,2,3,4}$ \\ ${ }^{1}$ Resource Ecology Group, Wageningen University, Wageningen, The Netherlands \\ ${ }^{2}$ Knowledge, Technology and Innovation Group, Wageningen University, Wageningen, The Netherlands \\ ${ }^{3}$ Scientific Services, Gonarezhou National Park, Chiredzi, Zimbabwe \\ ${ }^{4}$ School of Wildlife, Ecology and Conservation, Chinhoyi University of Technology, Chinhoyi, Zimbabwe \\ Email: egandiwa@gmail.com
}

Received 5 March 2014; revised 5 April 2014; accepted 12 April 2014

Copyright (c) 2014 by author and Scientific Research Publishing Inc.

This work is licensed under the Creative Commons Attribution International License (CC BY).

http://creativecommons.org/licenses/by/4.0/

(c) (1) 0 pen Access

\section{Abstract}

This article reviews: 1) The role of natural and human-induced controls in influencing large herbivore populations; 2 ) how human controls (i.e., policy instruments, incentives and provisions) influence human activities and wildlife conservation; and 3) media framing of wildlife conservation using Zimbabwe as a case study, in particular Gonarezhou National Park and adjacent areas. The review shows that droughts are important in influencing large herbivore populations in semi-arid ecosystems; political instability and economic collapse does not necessarily lead to increased illegal hunting in situations where policy instruments, such as laws, are enforced. A higher perceived effectiveness of Communal Areas Management Programme for Indigenous Resources was partly associated with a decline in human-wildlife conflicts and there was a spill-over effect of frames from the political domain into wildlife conservation following Zimbabwe's land reforms in 2000. It is concluded that natural bottom-up processes (e.g., droughts) influence large herbivore population dynamics whereas policy instruments, incentives, provisions and societal frames mainly have a top-down effect on wild large herbivore populations in savanna ecosystems.

\section{Keywords}

Bottom-Up Control, Illegal Hunting, Law Enforcement, Media Framing, Top-Down Control

\section{Introduction}

This article presents insights from a novel attempt to understand wildlife conservation issues in Zimbabwe

How to cite this paper: Gandiwa, E. (2014) Population Dynamics of Large Herbivores and the Framing of Wildlife Conservation in Zimbabwe. Open Journal of Ecology, 4, 411-420. http://dx.doi.org/10.4236/oje.2014.47036 
through focusing on scientific findings generated from interdisciplinary research [1] [2]. More specifically, this review primarily draws insights from a $\mathrm{PhD}$ research conducted in Zimbabwe, whose fieldwork covered the Gonarezhou National Park and the adjacent areas [3]. Generating information that help improve wildlife conservation and management through assessing the role of natural and human-induced top-down and bottom-up control of large herbivore populations and how policy instruments influence benefits and costs associated with community-based wildlife conservation in semi-arid savanna ecosystems is increasingly becoming important [4] [5]. Moreover, investigating the framing of wildlife conservation in the mass media following a political crisis and economic decline is essential in changing environments [6]. This article, therefore, specifically reviews the role of natural and human-induced controls, effectiveness of Communal Areas Management Programme for Indigenous Resources (CAMPFIRE) and human-wildlife conflicts and media framing in wildlife conservation using a case study of Zimbabwe.

In natural ecosystems, animal population sizes are largely controlled by two processes, namely top-down and bottom-up controls [7] [8]. Top-down control refers to processes whose effects flow down the food chain such as the herbivore populations being controlled by direct predation, and thus, carnivores indirectly influencing plant abundance. Bottom-up control refers to processes that control animal communities from the bottom of the food chain upward to higher trophic levels since plant primary production fuels the animal biota, plants, along with nutrients and light. Moreover, humans can also alter the terrestrial ecosystem structure and composition through actions such as setting fires and livestock grazing (human-induced bottom-up control), and by acting as a generalist super predator that can top-down harvest any animal species [4]. Figure 1 shows a model of relations of human-induced top-down and bottom-up controls of large herbivore populations in terrestrial ecosystems.

Community-based natural resources programs, such as the CAMPFIRE program developed in Zimbabwe, have been implemented to allow for the sustainable use of natural resources in areas bordering protected areas [9]. CAMPFIRE is a government initiative that was implemented in 1989 specifically to stimulate long-term development, management and sustainable use of natural resources in Zimbabwe's communal farming areas ad-

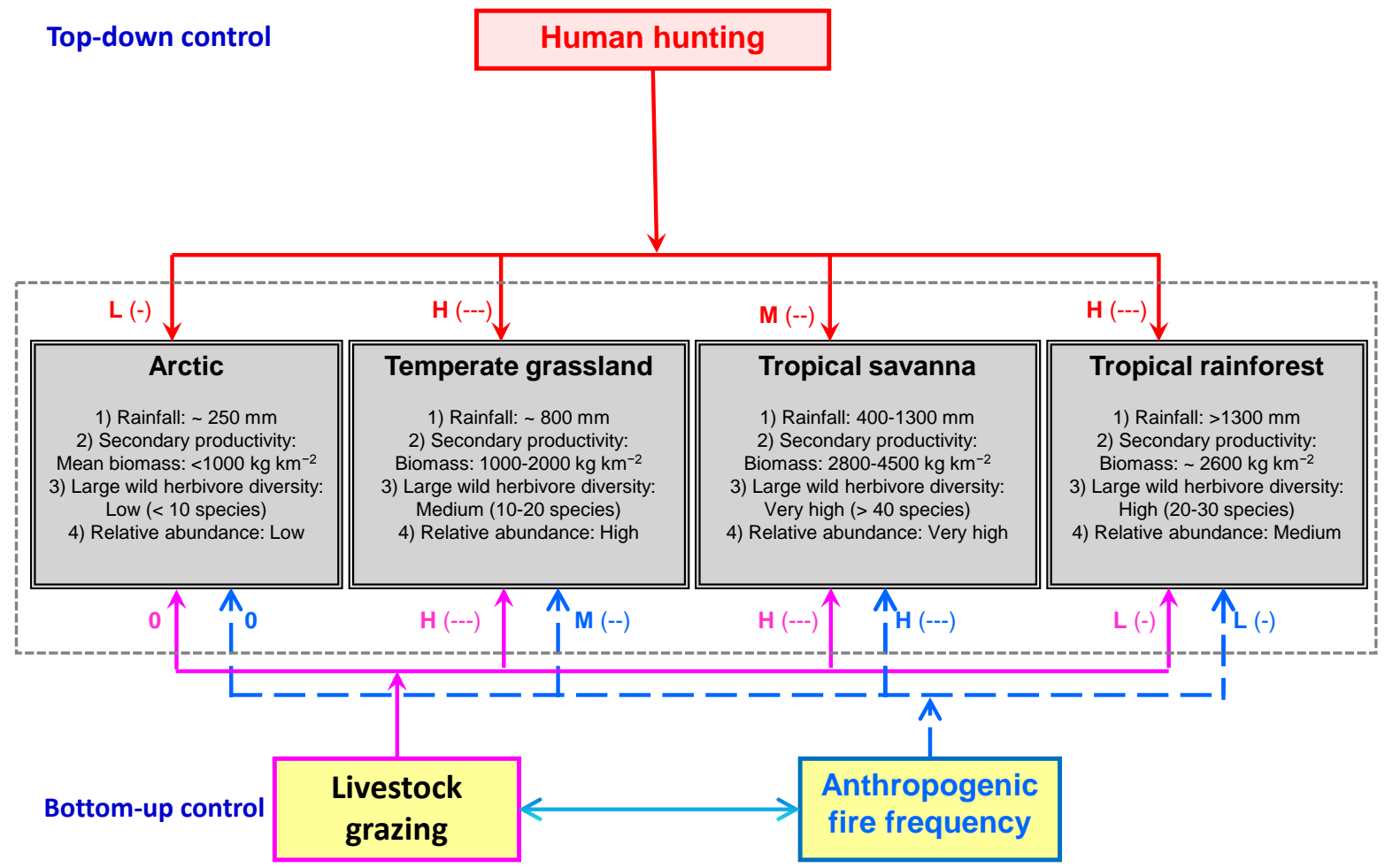

Figure 1. A schematic representation indicating the top-down and bottom-up controls of human activities (at global biome level) particularly on wild large herbivore community in the arctic, temperate grasslands, tropical savannas and tropical rainforests. Data sources: [21]-[23]. Notes: $\mathrm{H}=$ high negative impact, $\mathrm{M}=$ medium negative impact, and $\mathrm{L}=\mathrm{low}$ negative impact. Impact refers to negative human influence on specifically wild large herbivore populations and composition occurring in the various biomes, if and only if the outlined respective biome characteristics are satisfied. Source: [4]. 
jacent to state protected areas [10]. However, the effectiveness of the CAMPFIRE programs remains largely unknown due to the differences in human communities and the recent policy changes in Zimbabwe following the land reforms that occurred since 2000 which were largely published in both the local and international media, hence the importance of further research on CAMPFIRE effectiveness and also media framing of wildlife conservation.

\section{Natural Large Herbivore Population Controls}

Rainfall, in particular droughts, play a major role in influencing large herbivore population dynamics in semiarid savanna ecosystems with high rainfall variability [3]. Rainfall is a key driver of primary production in terrestrial ecosystems [11]-[13] and thus its influence on large herbivore population developments. Droughts are associated with a reduced primary production [13]-[15], which results in large animal die-offs due to forage shortages and also reduced surface water availability [16]-[18]. According to [3], evidence of a weak synchrony in the occurrence patterns of droughts and wet years was recorded in areas adjacent to the Gonarezhou National Park, Zimbabwe between 1970 and 2009. Populations of some large herbivore species declined following the 1992 drought in Gonarezhou National Park and subsequently increased after the drought. A similar trend in large herbivore population declines following the 1992 drought was also recorded in the adjacent Kruger National Park, South Africa [19] [20], suggesting a synchrony in large herbivore population development between these two adjacent protected areas [3]. Moreover, there was evidence to suggest that population growth was high when rainfall was average to above average for some consecutive period since the exceptionally wet periods did not lead to sudden increase in populations [3].

\section{Top-Down Human Control of Animal Populations}

Issues of illegal hunting have received considerable attention in recent years, particularly, in the tropical rainforest and savanna ecosystems [24]-[28], therefore, advancing our understanding of the negative impacts associated with human bushmeat hunting on animal communities and how law enforcement can influence such human bushmeat hunting in times of political crisis and economic collapse is of importance. Gandiwa et al. [29] used data gathered from 236 local people on perceptions of illegal hunting and wildlife protection in the northern Gonarezhou National Park and adjacent areas together with data collected from law enforcement patrols covering the period from 2000 and 2010, which coincided with the land reforms, political crisis and economic collapse in Zimbabwe. Main drivers of illegal hunting included bushmeat consumption at household level and the need to raise income for family or personal use as also reported by other authors [30]-[32]. Snaring was mostly used to catch a wide range of wild animals for bushmeat whereas firearms were used for large herbivore species such as elephant (Loxodonta africana), primarily for ivory. However, there was no evidence of massive large herbivore declines in Gonarezhou National Park between 2000 and 2010. This suggests that the negative impacts of the land reforms were low in Gonarezhou National Park, despite the fact that a small section (about $90 \mathrm{~km}^{2}$ ) of the northern part of the park had an illegal settlement since 2000 [33] [34].

\section{Adaptation to New Situations: Changes in Law Enforcement}

An increase in recorded illegal activities, i.e., hunting and fishing, was associated with reduced law enforcement efforts, between 2000 and 2003, as a result of few rangers and inadequate financial resources in Gonarezhou National Park [29]. However, when law enforcement staff numbers were increased in 2004 following the transformation of the wildlife authority into a parastatal and increased funding from the Frankfurt Zoological Society in the park, increased law enforcement efforts led to a decline in the numbers of arrested illegal hunters [29]. Illegal hunters appeared to have switched to snaring methods which are difficult to detect with increases in law enforcement as also reported by other authors [35]-[37]. This suggests that paying more attention to the detection of snares and their removal in protected areas is important, especially, when law enforcement efforts are increased.

Thus, [29] have shown that the variation in the recorded illegal activities in the northern Gonarezhou National Park ecosystem corresponds with the variations in law enforcement efforts. These findings, therefore, confirms that law enforcement is an important component of wildlife conservation in protected areas [38]-[40]. The increased law enforcement efforts inside Gonarezhou National Park and existence of community-based wildlife 
conservation programs in adjacent areas could also have helped in maintaining large herbivore populations inside the protected area [41] [42]. Further, there was no evidence in Gonarezhou National Park to suggest that illegal hunting had increased following the Zimbabwe's political crisis and economic collapse between 2000 and 2008. Similarly, the local people also attributed the perceived decline in illegal hunting between 2000 and 2010 to increased law enforcement by the wildlife authority [29]. This is in contrast to the media reports on general increase in illegal hunting across wildlife areas in Zimbabwe since 2000 [27].

\section{Socio-Ecological Systems and Wildlife Conservation}

The model shown in Figure 1 outlined the human-induced top-down and bottom-up controls of large herbivore populations in terrestrial ecosystems. However, the model does not include two important elements: 1) human controls which influences human behaviour, and 2) decision-making and framing processes, in particular media framing, which influences societal debates. Human controls are important in understanding the impact of human activities on large herbivore populations and also wildlife conservation hence the need to include this element in the model. Moreover, societal debates and decision making related to wild large herbivore population dynamics and associated wildlife conservation are informed not only by science but also by communication in, e.g., the mass media, thus, signifying the importance of including the element of decision-making and framing processes in the research model.

\subsection{Wildlife Conservation: Policy Instruments, Incentives and Provisions}

The findings of [43] suggest that human-wildlife conflicts are common even in communities with integrated conservation and development projects (ICDPs) as reported by other authors [44]-[46]. ICDPs play an important role in reducing human-wildlife conflicts through enabling communities to actively participate and derive economic benefits from natural resources management [47]-[49]. Community benefits under the CAMPFIRE program include infrastructural development, employment opportunities, cash dividends and a well-informed community on wildlife management issues and practices [43].

Of particular importance was the perceived increase in human-wildlife conflicts as a result of increasing wildlife populations in communities adjacent to the northern Gonarezhou National Park, e.g., elephant [3]. Similar, perceived increases in human-wildlife conflicts associated with increasing wildlife populations have been reported in northern Zimbabwe [50]. However, a high involvement of local people in the day-to-day running of CAMPFIRE was associated with lower perceived increase in human-wildlife conflicts since the local people were involved in decision making on aspects such as how to manage wildlife, income and human-wildlife conflicts [43].

Contextual factors, such as size (area) of the community, human population density and previous success of the CAMPFIRE programs across the local communities appeared to influence the perceived effectiveness of CAMPFIRE programs and attitudes towards problematic wildlife species in communities bordering the northern Gonarezhou National Park [43]. Moreover, the reduced benefits from CAMPFIRE programs associated with the hands-off reaction through the withdrawal of financial support by international donors following the recent land reforms in Zimbabwe appeared to have influenced perceptions of effectiveness of CAMPFIRE programs. This was also compounded by the high inflationary environment which led to the economic collapse in Zimbabwe, resulting in low response by safari operators or the local authorities to reported human-wildlife conflict cases, together with low benefits from CAMPFIRE in the local communities adjacent to the park [51] [52]. Low response rate incidences to human-wildlife conflicts to some extent led to the poisoning or hunting of problem animals [43] [53]. Carnivores, e.g., leopard (Panthera pardus), lion (Panthera leo) and spotted hyena (Crocuta crocuta), were more likely to be poisoned after livestock losses to large carnivores. Poisoning has also been reported in retaliation of human-wildlife conflicts across different ecosystems [53]-[55].

More favourable attitudes towards wildlife appeared to be associated with success of CAMPFIRE programs [43]. It can be hypothesised that the involvement of local people in decision making related to wildlife management issues and associated benefits accrued by the community from natural resources management programs plays an important role in influencing local people's attitude towards problem animal species. For instance, benefits and costs associated with wildlife-related conservation programs have been reported to influence attitudes towards animal species in some ecosystems [56]-[58]. 


\subsection{Decision-Making and Framing Processes}

Gandiwa et al. [6] concluded that images that exist in society are not necessarily congruent with reality on the ground, and that these images are influenced by other issues. In particular, findings by [42] [59] were at odds with the image of Zimbabwe mostly in the international media, thus it was valuable to better understand the role of mass media in framing wildlife conservation in Zimbabwe. This is important since societal decisions about wildlife conservation and management are not only taken on the basis of scientific information but also on what the mass media publishes. Using newspapers from countries with different relations to Zimbabwe, i.e., political, historical and conservation relations, [6] demonstrated that framing of wildlife conservation in the international media (United Kingdom and United States of America) was positive between 1989 and 1999 and then changed between 2000 and 2010, to being more negative. This change in framing was related to the land reforms that started in 2000 and legalized by the Zimbabwean Government in 2002. Thus, [6] concluded that a spill-over effect from a political-related phenomenon, i.e., land reforms, to a less political related issue, wildlife conservation, occurred. Between 2000 and 2010, newspaper articles in the international media blamed the Zimbabwean Government for the demise of wildlife and also challenges related to wildlife conservation in the country. However, the local Zimbabwean newspaper did not show any change in media frames before and after 2000.

Moreover, large herbivore population studies in Zimbabwe have showed that wildlife populations in state protected areas have either increased or remained stable [41] [59], whereas major wildlife declines were reported to have occurred in private-owned wildlife ranches or conservancies since the land reforms in year 2000 [60]-[62]. However, in the international newspaper articles, little attempt was made to distinguish this pattern of wildlife population decline with respect to land ownership following the land reforms in Zimbabwe. Hence, this type of misrepresentation of wildlife conservation in Zimbabwe in the international media is likely to have an influence on societal debates and decision making related to wildlife conservation issues and large herbivore population dynamics as shown in Figure 2.

\section{Practical Implications}

\subsection{Science-Society Interaction}

Gandiwa's [3] study inferred that there may be clear differences between dominant perspectives in society and the reality on the ground from a scientific investigation about wildlife conservation. The relationship between science and society is important in shaping people's views and also scientific research. Mass media is one way in which information from science is brought to the society and/or vice versa. Thus, [3] deduced that state protected areas were less negatively affected by the land reforms, political crisis and economic collapse between 2000 and 2010 than were private-owned wildlife areas. Therefore, the published international newspaper articles may not be accurate on the facts relating to wildlife conservation in Zimbabwe after the year 2000, due to the spill-over effect of a highly political related issue into a less political related issue of wildlife conservation [3] [6].

The media often neglect certain angles or frames of stories or neglect to provide evaluations of related events or issues [63]. Hence, the way that issues are framed can have a profound effect on the practical business of conservation because it defines agendas and limits the range of potential strategies that can be used to address problems [64]. There is need to address the negative image of wildlife conservation in Zimbabwe through: 1) ensuring that appropriate information is given in the international media so as to allow for support to conservation efforts by the international donors; 2) increased scientific research and dissemination of results in both scholarly and public media in order to really show the failure or success of conservation efforts in different land categories; and 3) hiring professional advertisement companies to counter publish representative wildlife conservation information about Zimbabwe into the opposing media.

Moreover, knowledge on large herbivore population trends, role of law enforcement and the need for local people involvement in decision making processes regarding problem animals generated by [3] is important in the societal arenas particularly in negotiations relating to natural resource use [2] and resource protection under the CAMPFIRE programs.

\subsection{Wildlife Management}

Management of wildlife in savanna ecosystems requires information on the factors controlling large herbivore populations, human interactions with ecosystems and how to control illegal activities. Gandiwa [3] recorded that 


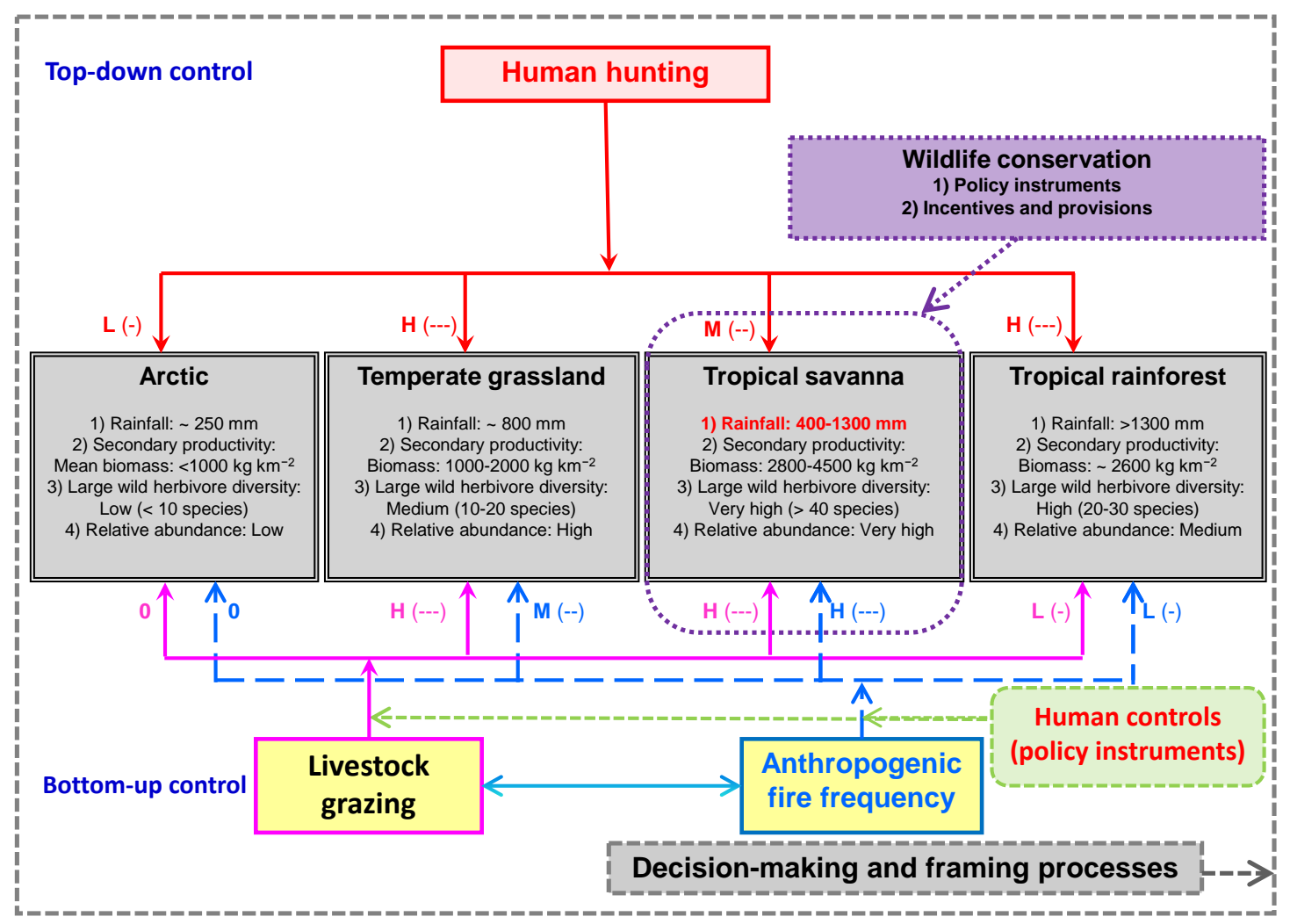

Figure 2. An adapted schematic representation indicating the natural and human-induced top-down and bottom-up controls (at global biome level) particularly on wild large herbivore communities in the arctic, temperate grasslands, tropical savannas and tropical rainforests. Improvements to the model in Figure 1:1) rainfall acts as a natural control in the tropical savanna (highlighted in red and bold); 2) policy instruments, e.g., law enforcement, help in reducing human hunting (top-down human control), livestock grazing in protected areas and anthropogenic fires whereas incentives and provisions help in dealing with problem animals; and 3) decision-making and framing processes about terrestrial ecosystems and wildlife conservation influences societal debates and wildlife management systems. Data sources: [21]-[23]. Notes: $\mathrm{H}=$ high negative impact, $\mathbf{M}=$ medium negative impact, and $\mathrm{L}=$ low negative impact. Impact refers to negative natural and human process influence on specifically wild large herbivore populations and composition occurring in the various biomes, if and only if the outlined respective biome characteristics are satisfied. Source:[3].

wet and drought occurrence patterns can vary in areas relatively close to each other (i.e., areas in the same climatic region). By identifying animal movement patterns and routes across different land-uses, managers could effectively remove or establish fences so as to allow free animal movements in wildlife areas during periods of resource scarcity. Currently, CAMPFIRE communities in Zimbabwe act as sinks for animals whereas the protected areas act as the sources, thereby expanding the habitat ranges of wildlife. Moreover, an understanding of animal movements is useful for managing cases of human-wildlife conflicts in CAMPFIRE communities [43] [65]. In addition, transboundary management of large herbivores [66] would also allow animals to move to less affected areas during droughts.

Research in Gonarezhou National Park shows that snaring becomes a major illegal hunting method with increasing law enforcement efforts [27] [29]. Thus, specifically having rangers trained in snare detection and removal would help reduce the negative impacts of snaring on wildlife. Further, management need to reduce the use of poisons in illegal hunting and retaliatory killing of wildlife through influencing policy to include stiffer penalties on use of pesticide and herbicides in wildlife killings since some of the illegally killed animals falls within the Near Threatened, Vulnerable and Lower Risk categories of the International Union for Conservation of Nature Red List of Threatened Species.

A high involvement of local people in decision making is important for the overall perceived effectiveness of CAMPFIRE programs [43]. Therefore, by ensuring that local people genuinely participate in community-based 
conservation programs, policy makers and wildlife managers may, thus, need to develop structures and policy instruments that enable local people to fully participate in conservation programs [67]. An investigation of local people involvement in decision making in wildlife conservation is needed for CAMPFIRE programs as this will allow for drawing lessons from both successful and unsuccessful CAMPFIRE communities which would help strengthen CAMPFIRE programs.

\section{Conclusion}

This review has provided valuable insights on understanding the influence of rainfall, particularly droughts, on large herbivore populations in savanna ecosystems. Wet and drought occurrence patterns somehow varied within the same climatic region with the 1992 severe drought having a negative impact on some large herbivore populations within a semi-arid savanna ecosystem [3]. Political crisis and economic collapse does not necessarily lead to increased illegal hunting in situations where law enforcement is strengthened [29]; and local people involvement in decision-making in natural resources conservation was highlighted as important in the perceived success of community-based natural resources programs [43]. Moreover, framing of wildlife conservation in changing environments, i.e., from a stable political and economic situation to political crisis and economic decline, was associated with the misrepresentation of wildlife issues due to a spill-over of political related issues to less politically related issues [6]. Thus, interdisciplinary research is valuable in understanding wildlife conservation issues in African savanna ecosystems which are dominated by human activities. To conclude, it is therefore suggested that natural controls (rainfall) influence large herbivore population dynamics whereas policy instruments, incentives, provisions and societal frames influence the human activities that affect wild large herbivore populations in savanna ecosystems.

\section{Acknowledgements}

The author is greatly indebted to Prof. Dr. Herbert H. T. Prins, Prof. Dr. Cees Leeuwis and Dr. Ignas M. A. Heitkönig for the valuable comments, suggestions and guidance. Comments from an anonymous reviewer are highly appreciated. This research was funded by the International Research and Education Fund of Wageningen University, The Netherlands.

\section{References}

[1] Marzano, M., Carss, D.N. and Bell, S. (2006) Working to Make Interdisciplinarity Work: Investing in Communication and Interpersonal Relationships. Journal of Agricultural Economics, 57, 185-197. http://dx.doi.org/10.1111/j.1477-9552.2006.00046.x

[2] Giller, K.E., Leeuwis, C., Andersson, J.A., Andriesse, W., Brouwer, A., Frost, P., Hebinck, P., Heitkönig, I., Van Ittersum, M.K., Koning, N., Ruben, R., Slingerland, M., Udo, H., Veldkamp, T., van de Vijver, C., van Wijk, M.T. and Windmeijer, P. (2008) Competing Claims on Natural Resources: What Role for Science. Ecology and Society, 13, 34. http://www.ecologyandsociety.org/vol13/iss2/art34/

[3] Gandiwa, E. (2013) The Numbers Game in Wildlife Conservation: Changeability and Framing of Large Mammal Numbers in Zimbabwe. Ph.D. Thesis, Wageningen University, Wageningen.

[4] Gandiwa, E. (2013) Top-Down and Bottom-Up Control of Large Herbivore Populations: A Review of Natural and Human-Induced Influences. Tropical Conservation Science, 6, 493-505.

[5] Grange, S. and Duncan, P. (2006) Bottom-Up and Top-Down Processes in African Ungulate Communities: Resources and Predation Acting on the Relative Abundance of Zebra and Grazing Bovids. Ecography, 29, 899-907. http://dx.doi.org/10.1111/j.2006.0906-7590.04684.x

[6] Gandiwa, E., Sprangers, S., van Bommel, S., Heitkönig, I.M.A., Leeuwis, C. and Prins, H.H.T. (2014) Spill-Over Effect in Media Framing: Representations of Wildlife Conservation in Zimbabwean and International Media, 1989-2010. Journal for Nature Conservation, in Press. http://dx.doi.org/10.1016/j.jnc.2014.03.009

[7] Hairston, N.G., Smith, F.E. and Slobodkin, L.B. (1960) Community Structure, Population Control, and Competition. American Naturalist, 94, 421-425. http://dx.doi.org/10.1086/282146

[8] Slobodkin, L.B. (1960) Ecological Energy Relationships at the Population Level. American Naturalist, 94, $213-236$. http://dx.doi.org/10.1086/282124

[9] Martin, R.B. (1986) Communal Areas Management Programme for Indigenous Resources (CAMPFIRE). CAMPFIRE Working Document No. 1/86. Branch of Terrestrial Ecology, Department of National Parks and Wild Life Manage- 
ment, Harare.

[10] Child, G. and Chitsike, L. (2000) “Ownership” of Wildlife. In: Prins, H.H.T., Grootenhuis, J.G. and Dolan, T.T., Eds., Wildlife Conservation by Sustainable Use, Kluwer Academic Publishers, Norwell, 247-266. http://dx.doi.org/10.1007/978-94-011-4012-6_12

[11] Coe, M.J., Cumming, D.H. and Phillipson, J. (1976) Biomass and Production of Large African Herbivores in Relation to Rainfall and Primary Production. Oecologia, 22, 341-354. http://dx.doi.org/10.1007/BF00345312

[12] East, R. (1984) Rainfall, Soil Nutrient Status and Biomass of Large African Savanna Mammals. African Journal of Ecology, 22, 245-270. http://dx.doi.org/10.1111/j.1365-2028.1984.tb00700.x

[13] Prins, H.H.T. and Loth, P.E. (1988) Rainfall Patterns as Background to Plant Phenology in Northern Tanzania. Journal of Biogeography, 15, 451-463. http://dx.doi.org/10.2307/2845275

[14] Drent, R.H. and Prins, H.H.T. (1987) The Herbivore as Prisoner of Its Food Supply. In: Andel, J.V., Bakker, J. and Snaydon, R.W., Eds., Disturbance in Grasslands: Species and Population Responses, Dr. W. Junk Publishing Company, Dordrecht, 131-147. http://dx.doi.org/10.1007/978-94-009-4055-0_9

[15] Vicente-Serrano, S.M., Gouveia, C., Camarero, J.J., Beguería, S., Trigo, R., López-Moreno, J.I., Azorín-Molina, C., Pasho, E., Lorenzo-Lacruz, J. and Revuelto, J. (2013) Response of Vegetation to Drought Time-Scales across Global Land Biomes. Proceedings of the National Academy of Sciences, 110, 52-57. http://dx.doi.org/10.1073/pnas.1207068110

[16] Knight, M.H. (1995) Drought-Related Mortality of Wildlife in the Southern Kalahari and the Role of Man. African Journal of Ecology, 33, 377-394. http://dx.doi.org/10.1111/j.1365-2028.1995.tb01047.x

[17] Foley, C., Pettorelli, N. and Foley, L. (2008) Severe Drought and Calf Survival in Elephants. Biology Letters, 4, 541544. http://dx.doi.org/10.1098/rsbl.2008.0370

[18] Duncan, C., Chauvenet, A.L.M., McRae, L.M. and Pettorelli, N. (2012) Predicting the Future Impact of Droughts on Ungulate Populations in Arid and Semi-Arid Environments. PloS ONE, 7, Article ID: e51490. http://dx.doi.org/10.1371/journal.pone.0051490

[19] Seydack, A.H., Grant, C.C., Smit, I.P., Vermeulen, W.J., Baard, J. and Zambatis, N. (2012) Large Herbivore Population Performance and Climate in a South African Semi-Arid Savanna. Koedoe, 54, Article ID: 1047. http://dx.doi.org/10.4102/koedoe.v54i1.1047

[20] Owen-Smith, N. and Ogutu, J. (2003) Rainfall Influences on Ungulate Population Dynamics in the Kruger National Park. In: du Toit, J.T., Rogers, K.H. and Biggs, H.C., Eds., The Kruger Experience: Ecology and Management of Savanna Heterogeneity, Island Press, Washington DC, 310-331.

[21] Barnes, R.F.W. and Lahm, S.A. (1997) An Ecological Perspective on Human Densities in the Central African Forest. Journal of Applied Ecology, 34, 245-260. http://dx.doi.org/10.2307/2404862

[22] Du Toit, J.T. and Cumming, D.H.M. (1999) Functional Significance of Ungulate Diversity in African Savannas and the Ecological Implications of the Spread of Pastoralism. Biodiversity and Conservation, 8, 1643-1661. http://dx.doi.org/10.1023/A:1008959721342

[23] Sala, O.E., Austin, A.T. and Vivanco, L. (2001) Temperate Grassland and Shrubland Ecosystems. In: Levin, S.A., Ed., Encyclopedia of Biodiversity, Academic Press, San Diego, 627-635. http://dx.doi.org/10.1016/B0-12-226865-2/00268-6

[24] Brashares, J.S., Arcese, P., Sam, M.K., Coppolillo, P.B., Sinclair, A.R.E. and Balmford, A. (2004) Bushmeat Hunting, Wildlife Declines, and Fish Supply in West Africa. Science, 306, 1180-1183. http://dx.doi.org/10.1126/science.1102425

[25] Hayward, M.W. (2009) Bushmeat Hunting in Dwesa and Cwebe Nature Reserves, Eastern Cape, South Africa. South African Journal of Wildlife Research, 39, 70-84. http://dx.doi.org/10.3957/056.039.0108

[26] Nielsen, M. (2011) Improving the Conservation Status of the Udzungwa Mountains, Tanzania? The Effect of Joint Forest Management on Bushmeat Hunting in the Kilombero Nature Reserve. Conservation and Society, 9, 106-118. http://dx.doi.org/10.4103/0972-4923.83721

[27] Gandiwa, E., Zisadza-Gandiwa, P., Mango, L. and Jakarasi, J. (2014) Law Enforcement Staff Perceptions of Illegal Hunting and Wildlife Conservation in Gonarezhou National Park, Southeastern Zimbabwe. Tropical Ecology, 55, 119127.

[28] Lindsey, P.A., Balme, G., Becker, M., Begg, C., Bento, C., Bocchino, C., Dickman, A., Diggle, R.W., Eves, H., Henschel, P., Lewis, D., Marnewick, K., Mattheus, J., Weldon McNutt, J., McRobb, R., Midlane, N., Milanzi, J., Morley, R., Murphree, M., Opyene, V., Phadima, J., Purchase, G., Rentsch, D., Roche, C., Shaw, J., Westhuizen, H.V.D., Vliet, N.V. and Zisadza-Gandiwa, P. (2013) The Bushmeat Trade in African Savannas: Impacts, Drivers, and Possible Solutions. Biological Conservation, 160, 80-96. http://dx.doi.org/10.1016/j.biocon.2012.12.020 
[29] Gandiwa, E., Heitkönig, I.M.A., Lokhorst, A.M., Prins, H.H.T. and Leeuwis, C. (2013) Illegal Hunting and Law Enforcement during a Period of Economic Decline in Zimbabwe: A Case Study of Northern Gonarezhou National Park and Adjacent Areas. Journal for Nature Conservation, 21, 133-142. http://dx.doi.org/10.1016/j.jnc.2012.11.009

[30] Holmern, T., Mkama, S., Muya, J. and Røskaft, E. (2006) Intraspecific Prey Choice of Bushmeat Hunters Outside the Serengeti National Park, Tanzania: A Preliminary Analysis. African Zoology, 41, 81-87. http://dx.doi.org/10.3377/1562-7020(2006)41[81:IPCOBH]2.0.CO;2

[31] Kümpel, N.F., Milner-Gulland, E.J., Cowlishaw, G. and Rowcliffe, J.M. (2010) Incentives for Hunting: The Role of Bushmeat in the Household Economy in Rural Equatorial Guinea. Human Ecology, 38, 251-264. http://dx.doi.org/10.1007/s10745-010-9316-4

[32] Macdonald, D.W., Johnson, P.J., Albrechtsen, L., Seymour, S., Dupain, J., Hall, A. and Fa, J.E. (2012) Bushmeat Trade in the Cross-Sanaga Rivers Region: Evidence for the Importance of Protected Areas. Biological Conservation, 147, 107-114. http://dx.doi.org/10.1016/j.biocon.2011.12.018

[33] Mombeshora, S. and Le Bel, S. (2009) Parks-People Conflicts: The Case of Gonarezhou National Park and the Chitsa Community in South-East Zimbabwe. Biodiversity and Conservation, 18, 2601-2623. http://dx.doi.org/10.1007/s10531-009-9676-5

[34] Gandiwa, P., Matsvayi, M., Ngwenya, M.M. and Gandiwa, E. (2011) Assessment of Livestock and Human Settlement Encroachment into Northern Gonarezhou National Park, Zimbabwe. Journal of Sustainable Development in Africa, 13, 19-33.

[35] Tumusiime, D.M., Eilu, G., Tweheyo, M. and Babweteera, F. (2010) Wildlife Snaring in Budongo Forest Reserve, Uganda. Human Dimensions of Wildlife, 15, 129-144. http://dx.doi.org/10.1080/10871200903493899

[36] Wato, Y.A., Wahungu, G.M. and Okello, M.M. (2006) Correlates of Wildlife Snaring Patterns in Tsavo West National Park, Kenya. Biological Conservation, 132, 500-509. http://dx.doi.org/10.1016/j.biocon.2006.05.010

[37] Becker, M., McRobb, R., Watson, F., Droge, E., Kanyembo, B., Murdoch, J. and Kakumbi, C. (2013) Evaluating WireSnare Poaching Trends and the Impacts of By-Catch on Elephants and Large Carnivores. Biological Conservation, 158, 26-36. http://dx.doi.org/10.1016/j.biocon.2012.08.017

[38] Fischer, F. (2008) The Importance of Law Enforcement for Protected Areas: Don’t Step Back! Be Honest—Protect! GAIA—Ecological Perspectives for Science and Society, 17, 101-103.

[39] Jachmann, H. and Billiouw, M. (1997) Elephant Poaching and Law Enforcement in the Central Luangwa Valley, Zambia. Journal of Applied Ecology, 34, 233-244. http://dx.doi.org/10.2307/2404861

[40] Holmern, T., Muya, J. and Røskaft, E. (2007) Local Law Enforcement and Illegal Bushmeat Hunting outside the Serengeti National Park, Tanzania. Environmental Conservation, 34, 55-63. http://dx.doi.org/10.1017/s0376892907003712

[41] Gandiwa, E., Heitkönig, I.M.A., Gandiwa, P., Matsvayi, W., Van Der Westhuizen, H. and Ngwenya, M.M. (2013) Large Herbivore Dynamics in Northern Gonarezhou National Park, Zimbabwe. Tropical Ecology, 54, 345-354.

[42] Dunham, K.M., van der Westhuizen, E., van der Westhuizen, H.F. and Gandiwa, E. (2010) Aerial Survey of Elephants and Other Large Herbivores in Gonarezhou National Park (Zimbabwe), Zinave National Park (Mozambique) and Surrounds: 2009. Zimbabwe Parks and Wildlife Management Authority, Harare.

[43] Gandiwa, E., Heitkönig, I.M.A., Lokhorst, A.M., Prins, H.H.T. and Leeuwis, C. (2013) CAMPFIRE and HumanWildlife Conflicts in Communities Adjacent to the Northern Gonarezhou National Park, Zimbabwe. Ecology and Society, 18, 7. http://dx.doi.org/10.5751/ES-05817-180407

[44] Michalski, F., Boulhosa, R.L.P., Faria, A. and Peres, C.A. (2006) Human-Wildlife Conflicts in a Fragmented Amazonian Forest Landscape: Determinants of Large Felid Depredation on Livestock. Animal Conservation, 9, 179-188. http://dx.doi.org/10.1111/j.1469-1795.2006.00025.x

[45] Anthony, B.P., Scott, P. and Antypas, A. (2010) Sitting on the Fence? Policies and Practices in Managing HumanWildlife Conflict in Limpopo Province, South Africa. Conservation and Society, 8, 225-240. http://dx.doi.org/10.4103/0972-4923.73812

[46] Gore, M.L. and Kahler, J.S. (2012) Gendered Risk Perceptions Associated with Human-Wildlife Conflict: Implications for Participatory Conservation. PloS ONE, 7, Article ID: e32901. http://dx.doi.org/10.1371/journal.pone.0032901

[47] Child, B. (2000) Making Wildlife Pay: Converting Wildlife’s Comparative Advantage into Real Incentives for Having Wildlife in African Savannas, Case Studies from Zimbabwe and Zambia. In: Prins, H.H.T., Grootenhuis, J.G. and Dolan, T.T., Eds., Wildlife Conservation by Sustainable Use, Kluwer Academic Publishers, Boston, 335-387. http://dx.doi.org/10.1007/978-94-011-4012-6_17

[48] Prins, H.H.T., Grootenhuis, J.G. and Dolan, T.T. (2000) Wildlife Conservation by Sustainable Use. Kluwer Academic Publishers, Boston. http://dx.doi.org/10.1007/978-94-011-4012-6 
[49] Heitkönig, I.M.A. and Prins, H.H.T. (2009) Land Use in Zimbabwe and Neighbouring Southern African Countries. In: Boersema, J.J. and Reijnders, L., Eds., Principles of Environmental Sciences, SpringerNetherlands, Berlin, 445-457. http://dx.doi.org/10.1007/978-1-4020-9158-2_22

[50] Mutandwa, E. and Gadzirayi, C.T. (2007) Impact of Community-Based Approaches to Wildlife Management: Case Study of the CAMPFIRE Programme in Zimbabwe. International Journal of Sustainable Development \& World Ecology, 14, 336-344. http://dx.doi.org/10.1080/13504500709469734

[51] Balint, P. and Mashinya, J. (2006) The Decline of a Model Community-Based Conservation Project: Governance, Capacity, and Devolution in Mahenye, Zimbabwe. Geoforum, 37, 805-815. http://dx.doi.org/10.1016/j.geoforum.2005.01.011

[52] Balint, P.J. and Mashinya, J. (2008) CAMPFIRE during Zimbabwe’s National Crisis: Local Impacts and Broader Implications for Community-Based Wildlife Management. Society \& Natural Resources, 21, 783-796. http://dx.doi.org/10.1080/08941920701681961

[53] Gandiwa, E. (2011) Preliminary Assessment of Illegal Hunting by Communities Adjacent to the Northern Gonarezhou National Park, Zimbabwe. Tropical Conservation Science, 4, 445-467.

[54] Kalaivanan, N., Venkataramanan, R., Sreekumar, C., Saravanan, A. and Srivastava, R.K. (2011) Secondary Phorate Poisoning of Large Carnivores in India. European Journal of Wildlife Research, 57, 191-194. http://dx.doi.org/10.1007/s10344-010-0433-6

[55] Mateo-Tomás, P., Olea, P.P., Sánchez-Barbudo, I.S. and Mateo, R. (2012) Alleviating Human-Wildlife Conflicts: Identifying the Causes and Mapping the Risk of Illegal Poisoning of Wild Fauna. Journal of Applied Ecology, 49, 376385. http://dx.doi.org/10.1111/j.1365-2664.2012.02119.x

[56] Gillingham, S. and Lee, P.C. (1999) The Impact of Wildlife-Related Benefits on the Conservation Attitudes of Local People around the Selous Game Reserve, Tanzania. Environmental Conservation, 26, 218-228. http://dx.doi.org/10.1017/s0376892999000302

[57] Scanlon, L.J. and Kull, C.A. (2009) Untangling the Links between Wildlife Benefits and Community-Based Conservation at Torra Conservancy, Namibia. Development Southern Africa, 26, 75-93. http://dx.doi.org/10.1080/03768350802640107

[58] Karanth, K.K. and Nepal, S.K. (2012) Local Residents Perception of Benefits and Losses from Protected Areas in India and Nepal. Environmental Management, 49, 372-386. http://dx.doi.org/10.1007/s00267-011-9778-1

[59] Valeix, M., Fritz, H., Chamaillé-Jammes, S., Bourgarel, M. and Murindagomo, F. (2008) Fluctuations in Abundance of Large Herbivore Populations: Insights into the Influence of Dry Season Rainfall and Elephant Numbers from LongTerm Data. Animal Conservation, 11, 391-400. http://dx.doi.org/10.1111/j.1469-1795.2008.00194.x

[60] Lindsey, P.A., Romanãch, S.S., Matema, S., Matema, C., Mupamhadzi, I. and Muvengwi, J. (2011) Dynamics and Underlying Causes of Illegal Bushmeat Trade in Zimbabwe. Oryx, 45, 84-95.

http://dx.doi.org/10.1017/S0030605310001274

[61] Chaumba, J., Scoones, I. and Wolmer, W. (2003) From Jambanja to Planning: The Reassertion of Technocracy in Land Reform in Southeastern Zimbabwe? The Journal of Modern African Studies, 41, 533-554. http://dx.doi.org/10.1017/S0022278X03004397

[62] Wolmer, W., Chaumba, J. and Scoones, I. (2004) Wildlife Management and Land Reform in Southeastern Zimbabwe: A Compatible Pairing or a Contradiction in Terms? Geoforum, 35, 87-98. http://dx.doi.org/10.1016/s0016-7185(03)00031-9

[63] Entman, R.M. (2004) Projections of Power: Framing News, Public Opinion, and US Foreign Policy. University of Chicago Press, Chicago.

[64] Ferrier, E.A. and Larson, B.M.H. (2012) Biodiversity and Conservation Framing in Canada: A Case Study of the Oak Ridges Moraine. Zeitschrift für Kanada-Studien, 32, 107-125.

[65] Ogutu, J.O., Reid, R.S., Piepho, H.P., Hobbs, N.T., Rainy, M.E., Kruska, R.L., Worden, J.S. and Nyabenge, M. (2014) Large Herbivore Responses to Surface Water and Land Use in an East African Savanna: Implications for Conservation and Human-Wildlife Conflicts. Biodiversity and Conservation, 23, 573-596. http://dx.doi.org/10.1007/s10531-013-0617-y

[66] van Aarde, R.J. and Jackson, T.P. (2007) Megaparks for Metapopulations: Addressing the Causes of Locally High Elephant Numbers in Southern Africa. Biological Conservation, 134, 289-297. http://dx.doi.org/10.1016/j.biocon.2006.08.027

[67] Rihoy, E. and Mugaranyanga, B. (2007) Devolution and Democratisation of Natural Resource Management in Southern Africa: A Comparative Analysis of CBNRM Policy Processes in Botswana and Zimbabwe. Commons Southern Africa, Paper No. 18, 62 pp., CASS/PLAAS Occasional Paper Series. http://www.uwc.ac.za/plaas 